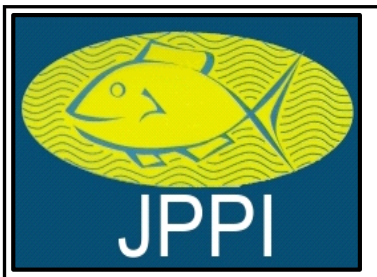

Tersedia online di: http://ejournal-balitbang.kkp.go.id/index.php/jppi

e-mail:jppi.puslitbangkan@gmail.com

JURNAL PENELITIANPERIKANANINDONESIA

Volume 26 Nomor 2 Juni 2020

p-ISSN: 0853-5884

e-ISSN: 2502-6542

Nomor Akreditasi RISTEKDIKTI: 21/E/KPT/2018

\title{
STRUKTUR KOMUNITAS IKAN KARANG DI PERAIRAN PESISIR KENDARI SULAWESI TENGGARA
}

\section{COMMUNITY STRUCTURES OF REEF-FISHES IN THE ADJACENT KENDARI'S REEF WATERS, SOUTHEAST SULAWESI}

\author{
Isa Nagib Edrus ${ }^{* 1}$ dan Tri Aryono Hadi² \\ ${ }^{1}$ Balai Riset Perikanan Laut - KKP Jl. Raya Jakarta Bogor, Cibinong, Jawa Barat, Indonesia \\ ${ }^{2}$ Pusat Penelitian Oseanografi - LIPI JI. Pasir Putih I Ancol Timur, Jakarta 14430, Indonesia \\ Teregistrasi I tanggal: 25 Agustus 2019; Diterima setelah perbaikan tanggal: 23 April 2020; \\ Disetujui terbit tanggal: 04 Mei 2020
}

\begin{abstract}
ABSTRAK
Ekosistem terumbu karang di Kawasan Pesisir Kendari sangat dipengaruhi oleh aktivitas pembangunan di daratan utama seperti sedimentasi yang berkepanjangan. Hal ini dapat berpengaruh pada tutupan karang dan kecerahan air laut, dan sebagai konsekuensinya adalah terjadinya perubahan struktur komunitas ikan karang. Keanekaragaman ikan karang diasumsikan akan menurun ketika terjadi kerusakan yang meluas pada terumbu karang dan dalam waktu yang panjang. Tujuan penelitian adalah untuk mengidentifikasi kondisi sumberdaya ikan karang melalui kajian struktur komunitas ikan karang. Penelitian ini dilakukan pada bulan September 2018 di perairan karang pesisir Kendari, Sulawesi Tenggara. Metode yang digunakan dalam kegiatan ini adalah sensus visual bawah air dengan transek sabuk pada 10 lokasi penelitian. Hasil penelitian menemukan 195 spesies ikan karang yang terdiri dari 93 spesies kelompok mayor, 89 jenis kelompok ikan target, dan 13 jenis kelompok ikan indikator. Dari 10 lokasi transek, hanya 4 stasiun yang memiliki nilai indeks keanekaragaman antara 3,0-3,6, indeks dominansi antara 0,04-0,10 dan indeks keseragaman antara $0,8-0,9$, serta 5 stasiun memiliki indeks kekayaan jenis antara 7,8 hingga 10,5. Keanekaragaman jenis ikan termasuk rendah, komunitas didominasi oleh kelompok ikan mayor, dan kepadatan stok ikan karang tergolong rendah pada semua stasiun.
\end{abstract}

Kata Kunci: Ikan karang; struktur komunitas; Kendari; Sulawesi Tenggara

\begin{abstract}
Coral reef ecosystems in Kendari coastal area were affected by mainland development as well as long-term sedimentation. Those activities influencing coral coverage and sea water tranparency lead to the changes in reef fish structure communities. The study objective is to identify the condition of reef-fishes by analyzing theirin terms of a community structures. This study was carried out in September 2018 at the adjacent Kendari's reef waters, Southeast Sulawesi. The method used in this study was the underwater visual cencus using belt transects at ten study sites. The results of the study successfully identified about 195 species of reef fishes, consisted of 93 species of major-fish group, 89 species of target-fish group, and 13 species of indicator-fish group. Species compositions among the study sites ranged from 39 species to 74 species. Among the 10 transect sites, four sites had fish diversity indices ranging from 3.0 to 3.6, dominance indices ranging from $0.04-0.1$, and evenness indices ranging from 0.8 to 0.9, whereas 5 transect sites had species richness levels ranging from 7.8 to 10.5. For all study sites, the reef fishes diversities were in low levels, reef fishes communities were dominated by major-fish groups, and the density of fish stocks were classified in low levels.
\end{abstract}

Keywords: Reef fishes; community structure; Kendari; Southeast Sulawesi 


\section{PENDAHULUAN}

Ikan karang berasosiasi sangat kuat pada ekosistem terumbu karang. Co-evolusi antara ikan dan terumbu karang sebagai habitatnya terjadi seiring perubahan tutupan karang dan peran ikan karang dalam mendukung proses resiliensi pada karang. Beberapa hasil penelitian menyebutkan bahwa terdapat hubungan yang signifikan antara tutupan karang hidup dengan kelimpahan dan keanekaragaman ikan karang, sehingga dari suatu area karang ke area karang yang lain terlihat adanya perbedaan keanekaragaman ikan karang (Feary et al., 2007a). Perubahan-perubahan keanekaragaman ikan karang atau komposisi dalam komunitas ikan dapat terjadi karena adanya perubahan-perubahan substrat karang. Keanekaragaman ikan karang akan menurun ketika terjadi kerusakan yang meluas pada terumbu karang dalam waktu yang berkepanjangan (Jones \& Syms, 1998; Halford et al., 2004; Jones et al., 2004; Graham et al., 2006; Wilson et al., 2006). Keanekaragaman ikan karang terutama kelompok herbivora, memiliki arti penting dalam memelihara pertumbuhan karang. Kelompok herbivora memiliki peran penting dalam mengontrol pertumbuhan alga dan memberikan kesempatan untuk tumbuhkembangnya planula karang yang baru (Green \& Bellwood, 2009; Obura\& Grimsdith, 2009).

Kelompok ikan major adalah kelompok ikan yang umumnya mempunyai ukuran tubuh yang kecil dan hidup secara berkoloni di ekosistem terumbu karang (English et al., 1997). Ikan ini jarang dimanfaatkan sebagai ikan konsumsi, namun ikan ini mempunyai peraran yang penting dalam ekosistem terumbu karang. Sebagian besar ikan major adalah komoditas penting sebagai ikan hias.

Kehadiran ikan pada area pesisir ditentukan oleh banyak faktor, di antaranya adalah kesukaan ikan pada jenis karang batu tertentu karena adanya sifat fungsional ikan pada relung ekologi (ecologicalniches) (Stan \& Hauter, 2011), respon ikan pada kecerahan perairan karena kemudahan pemangsaan (Wenger,
2009), respon ikan pada subtrat perairan tertentu karena kebutuhan proteksi (Lieske \& Myers, 1997) dan spesialisasi ikan pada relung ekologisnya (Nybakken, 1992). Berdasarkan hal tersebut ikan dapat memilih untuk menetap karena sesuai atau meninggalkan habitatnya karena fungsi dan spesialisasinya terganggu. Pilihan tersebut tentu saja merupakan refleksi dari kondisi dan daya dukung habitat ikan dan kompleksitas substrat terumbu sangat menentukan struktur komunitas ikan karang (Feary et al., 2007b; Roberts \& Ormond, 1987).

Jumlah dan ukuran ikan karang merupakan indikator kesehatan ekosistem karang secara menyeluruh. Komunitas ikan karang adalah suatu yang potensial dalam memberikan gambaran dini atas proses alami oseanografis, seperti misalnya respon atas upwelling nutrisi dan gangguan akibat tangkap lebih, polusi dan pengaruh iklim (Odum, 1975; Gomez \& Yap, 1988; NOAA, 2019).

Terumbu karang ketika didukung oleh perairan yang sehat dan pengelolaan yang baik akan meningkatkan keanekaragaman komunitas ikan. Sebaliknya, pada lingkungan hidup yang memburuk hanya populasi tertentu yang bertahan dan berkembang, dimana populasi tersebut akan mendominasi dalam komunitas dan kemudian terjadi perubahan komposisi jenis, komposisi individu dan akhirnya terjadi penurunan nilai keanekaragaman ikan (Odum, 1975; Arief \& Edrus, 2010).

Penelitian ini bertujuan untuk mengidentifikasi struktur komunitas ikan karang yang meliputi keanekaragaman, komposisi dan kepadatan stok ikan karang. Hasil penelitian ini diharapkan bermanfaat sebagai bahan masukan kebijakan dalam pengelolaan perikanan di wilayah pesisir.

\section{BAHAN DAN METODE}

Penelitian dilakukan pada September 2018, khususnya di perairan terumbu karang sekitar Pesisir Kendari dan Tinobu (Gambar 1 dan Tabel 1). 


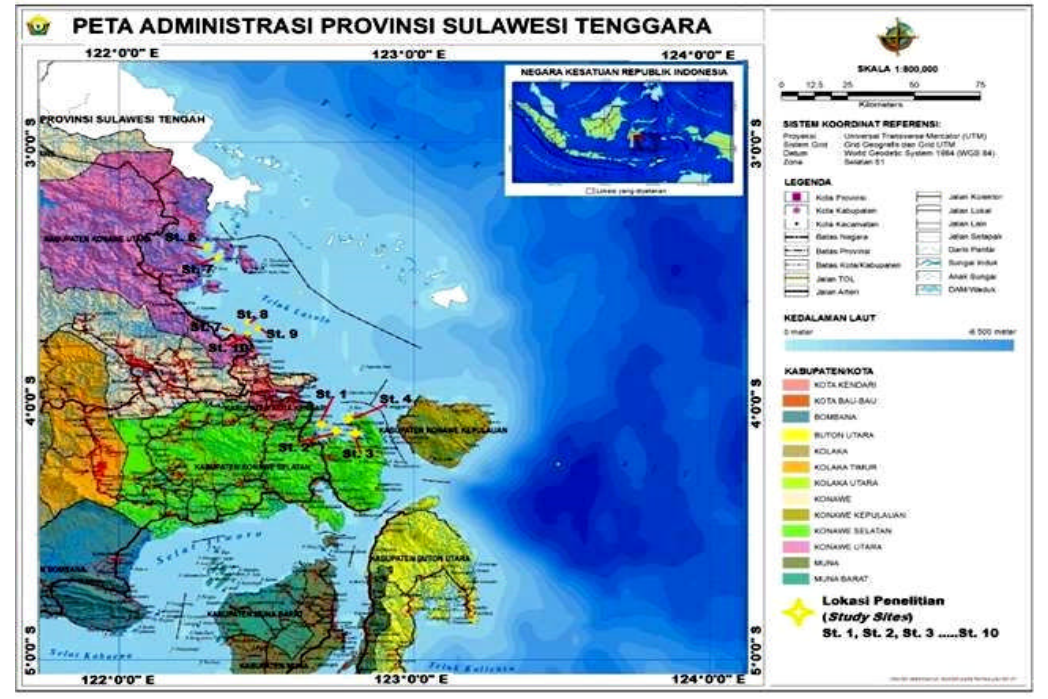

Gambar 1. Lokasi penelitian di perairan terumbu karang sekitar Kendari dan Tinobu.

Figure 1. Study sites in around of the Kendari and Tinobu reef waters.

Tabel 1. Posisi geografis lokasi penelitian di perairan Kendari dan Tinobu

Table 1. Study sites in around of the Kendari and Tinobu waters

\begin{tabular}{cccc}
\hline \hline $\begin{array}{c}\text { KODE STASIUN / } \\
\text { Station Codes }\end{array}$ & $\begin{array}{c}\text { LINTANG / } \\
\text { Latitude }\end{array}$ & $\begin{array}{c}\text { BUJUR / } \\
\text { Longitude) }\end{array}$ & NAMA LOKASI / Location Names \\
\hline St. 1 & $04.13154^{\circ}$ & $122.70640^{\circ}$ & Toli-Toli \\
St. 2 & $04.12864^{\circ}$ & $122.72789^{\circ}$ & Wowo Sunggu \\
St. 3 & $04.12926^{\circ}$ & $122.80884^{\circ}$ & Pulau Gala \\
St. 4 & $04.10349^{\circ}$ & $122.80043^{\circ}$ & Labutaone \\
St. 5 & $03.43308^{\circ}$ & $122.80043^{\circ}$ & Boidingin 1 \\
St. 6 & $03.42880^{\circ}$ & $122.35154^{\circ}$ & Boidingin 2 \\
St. 7 & $03.74257^{\circ}$ & $122.43377^{\circ}$ & Laimeo \\
St. 8 & $03.71866^{\circ}$ & $122.46698^{\circ}$ & Gosong Laimeo 1 \\
St. 9 & $03.72544^{\circ}$ & $122.46821^{\circ}$ & Gosong Laimeo 2 \\
St.10 & $03.74768^{\circ}$ & $122.41386^{\circ}$ & Tanjung Taipa \\
\hline \hline
\end{tabular}

Metode yang digunakan dalam penelitian ini adalah metode sensus visual pada transek sabuk (English et al., 1997). Sensus visual dikerjakan oleh penyelam sepanjang garis transek 70 meter, dengan luas area sensus $(70 \times 5) \mathrm{m}^{2}$. Jenis dan perkiraan jumlah ikan dicatat dalam lembar data kertas kedap air. Identifikasi jenis ikan menggunakan buku petunjuk bergambar (Kuiter \& Tonozuka, 2001; Lieske \& Myers, 1997; Masuda et al., 1984)

Analisis keragaman hayati ikan karang dilakukan dengan menggunakan berbagai indek ekologi (Kreb, 1989) seperti di bawah ini.

Indeks Margalef $\mathrm{R}=(\mathrm{S}-1) / \mathrm{ln}(\mathrm{n})$.

Indeks Simpson-D $=a ̊ a\left(n_{i}\left(n_{i}-1\right) /(N(N-1)\}\right.$

Indeks Shannon Weaver $\mathrm{H}=\mathrm{S}\left\{(\mathrm{n} / \mathrm{N}) \ln \left(\mathrm{n}_{i} / \mathrm{N}\right)\right\}$.

Indeks Pielou $\mathrm{E}_{1}=\{\mathrm{H} / \ln (\mathrm{S})\}$
Dengan keterangan: $\mathrm{R}=$ Indeks Kekayaan Jenis, $\mathrm{D}=$ Indeks Dominasi, $\mathrm{H}=$ Indeks Keanekaragaman Shannon, $\mathrm{E}=$ Indeks Kemerataan, $\mathrm{n}_{\mathrm{i}}=$ jumlah ikan jenis ke I, $\mathrm{N}$ = total individu ikan untuk semua jenis danS = banyaknya jenis.

\section{HASILDAN BAHASAN \\ Hasil}

\section{Komposisi Jenis Ikan Karang}

Komposisi jenis ikan karang yang berhasil diidentifikasi untuk semua area transek di 10 stasiun penelitian adalah 195 jenis. Jumlah tersebut terdiri dari 32 suku ikan karang (Tabel 2). Suku yang paling banyak jenisnya antara lain Pomacentridae (38), Labridae (37), Chaetodontidae (13), Acanthuridae (13), Serranidae (12), Scaridae, (10), Nemipteridae (9), Apogonidae (7), Siganidae (7), dan Casionidae (5). 
Komposisi ikan karang bervariasi pada setiap stasiun penelitian dengan kecenderungan yang sama (Tabel 3) dengan komposisi didominasi kelompok major (rata-rata $75 \%$ ) yang merupakan kelompok terbesar yang ditemukan pada terumbu karang di mana saja. Kelompok ikan target menyumbang rata-rata $23 \%$ pada komunitas ikan karang, sementara kelompok ikan indikator ditemukan rata-rata $2 \%$.

Penelitian ini menemukan total kelompok ikan major sebanyak 93 spesies dari 14 suku. Kelompok ikan target dijumpai sebanyak 89 jenis dari 19 suku dan kelompok ikan indikator sebanyak 13 spesies dari suku Chaetodontidae. Sebaliknya secara khusus dalam kategori lokal, jumlah spesies yang ditemukan antar stasiun penelitian adalah bervariasi dan jumlahnya lebih rendah dari komposisi spesies secara umum. Masing-masing variasi kelompok ikan major antara 16 sampai 34 spesies, ikan target antara 19 sampai 37 spesies, dan kelompok ikan indikator antara 2 sampai 5 spesies (Tabel 3 ). Dengan demikian tidak semua lokasi memiliki tingkat kekayaan dan keanekaragaman yang tinggi.

Tabel 2. Jumlah spesies ikan karang menurut suku dan lokasi stasiun penelitian

Table 2. Species numbers of reef fishes based on families and study sites

\begin{tabular}{|c|c|c|c|c|c|c|c|c|c|c|c|c|c|}
\hline \multirow{2}{*}{ NO. } & \multirow{2}{*}{ SUKU/ Families } & \multicolumn{11}{|c|}{$\begin{array}{l}\text { JUMLAH JENIS MENURUT SUKU DAN STASIUN / } \\
\text { Species Numbers by Families and Study Sites }\end{array}$} & \multirow{2}{*}{$\begin{array}{c}\text { Kelompok } \\
\text { / Group }\end{array}$} \\
\hline & & $\begin{array}{l}5 \\
5\end{array}$ & ำ & $\begin{array}{l}8 \\
\dot{5} \\
\qquad\end{array}$ & $\begin{array}{l}\text { ठ } \\
\qquad 5\end{array}$ & $\begin{array}{l}\qquad 8 \\
\qquad \\
\qquad\end{array}$ & $\begin{array}{l}8 \\
\qquad \\
\qquad\end{array}$ & $\begin{array}{l}5 \\
\vdots \\
\qquad\end{array}$ & $\begin{array}{l}\infty \\
\text { 心 }\end{array}$ & $\begin{array}{l}8 \\
\qquad \\
\text { c }\end{array}$ & $\frac{0}{5}$ & Total & \\
\hline 1 & POMACENTRIDAE & 21 & 21 & 11 & 8 & 10 & 7 & 8 & 10 & 6 & 16 & 38 & Major \\
\hline 2 & $\angle A B R I D A E$ & 10 & 7 & 8 & 9 & 7 & 7 & 17 & 17 & 16 & 21 & 37 & Major \\
\hline 3 & CHAETODONTIDAE & 2 & 3 & 3 & 5 & 5 & 4 & 2 & 2 & 4 & 3 & 13 & Indikator \\
\hline 4 & ACANTHURIDAE & & 1 & 2 & & 3 & 3 & 4 & 6 & 5 & 5 & 13 & Target \\
\hline 5 & SERRANIDAE & 2 & 3 & 7 & 3 & 2 & & 1 & 2 & 2 & 3 & 12 & Target \\
\hline 6 & SCARIDAE & 5 & 3 & 2 & 2 & 3 & 4 & 5 & 6 & 5 & 6 & 10 & Target \\
\hline 7 & NEMIPTERIDAE & 2 & 2 & 1 & & 1 & 1 & 1 & 2 & 4 & & 9 & Target \\
\hline 8 & APOGONIDAE & 1 & 7 & 3 & 4 & 5 & 4 & & & & & 7 & Major \\
\hline 9 & SIGANIDAE & 1 & 4 & 3 & 3 & 4 & 2 & 5 & 1 & 3 & 3 & 7 & Target \\
\hline 10 & CAESIONIDAE & 2 & 2 & 3 & 4 & 2 & & 1 & 2 & 1 & & 5 & Target \\
\hline 11 & BALISTIDAE & 2 & & 1 & & & 1 & 3 & 4 & 3 & 1 & 5 & Target \\
\hline 12 & LUTJANIDAE & & 2 & 1 & 1 & 3 & 3 & & 1 & & 2 & 4 & Target \\
\hline 13 & POMACANTHIDAE & 1 & 2 & 1 & 2 & 1 & 1 & 2 & & & 1 & 4 & Major \\
\hline 14 & BLENNIIDAE & 1 & 1 & 1 & 1 & 2 & & & 1 & & & 3 & Major \\
\hline 15 & GOBIDAE & & & & & 1 & & & 2 & & & 3 & Major \\
\hline 16 & TETRAODONTIDAE & 1 & 2 & & & 1 & & 1 & 2 & 2 & & 3 & Major \\
\hline 17 & CARANGIDAE & 1 & 2 & & 1 & & & & & 1 & 1 & 3 & Target \\
\hline 18 & HOLOCENTRIDAE & & & & & 2 & & & & & 1 & 2 & Target \\
\hline 19 & AULOSTOMIDAE & & 2 & 1 & & & & & & 1 & 1 & 2 & Major \\
\hline 20 & LETHRINIDAE & & & & & & & & & & 2 & 2 & Target \\
\hline 21 & MULLIDAE & 2 & & 1 & & & & 1 & 2 & 2 & & 2 & Target \\
\hline 22 & GOBIESOCIDAE & & 1 & & 1 & & & & & & & 1 & Major \\
\hline 23 & FISTULARIIDAE & & & & 1 & & & 1 & & & & 1 & Major \\
\hline 24 & ANTHIIDAE & & & & & & & & 1 & & 1 & 1 & Major \\
\hline 25 & GRAMMISTIDAE & & 1 & & 1 & 1 & 1 & & & 1 & 1 & 1 & Target \\
\hline 26 & CIRRHITIDAE & & & & & & & 1 & 1 & & 1 & 1 & Major \\
\hline 27 & HAEMULIDAE & & & & & & & 1 & & 1 & 1 & 1 & Target \\
\hline 28 & PRIACANTHIDAE & & & & & & & & & & 1 & 1 & Target \\
\hline 29 & PHEMPHERIDIDAE & & & & & & & & & & 1 & 1 & Target \\
\hline 30 & EPHIPPIDAE & & 1 & & & & & & & & & 1 & Target \\
\hline 31 & PINGUIPEDIDAE & & & 1 & & & & 1 & 1 & & & 1 & Major \\
\hline 32 & ZANCLIDAE & 1 & 1 & 1 & 1 & 1 & 1 & 1 & 1 & 1 & 1 & 1 & Major \\
\hline
\end{tabular}

Hasil analisis data yang disajikan pada Tabel 4menunjukkan bahwa hanya stasiun 07, 08 dan 09 yang memiliki status kekayaan jenis dan keanekaragaman tinggi, kerena memiliki indeks kemerataan antara populasi yang relatif baik dibandingkan dengan stasiun lain. Stasiun 10 memiliki kekayaan jenis tertinggi, seperti juga pada Stasiun
02, tetapi nilai keanekaragamannya tergolong rendah. Hal ini karena indeks dominasi lebih tinggi dari nilainya di stasiun lain, sementara indeks kemerataan populasi rendah. Ketika komunitas ikan karang didominasi oleh sedikit jenisyang mampu berkembang, maka hal ini menujukkan keanekaragaman yang menurun. 
Tabel 3. Struktur komunitas ikan karang menurut kelompok fungsional

Table 3. Community structures of reef fishes by functional groups

\begin{tabular}{|c|c|c|c|c|c|c|c|c|c|c|c|}
\hline \multirow{2}{*}{$\begin{array}{l}\text { DESKRIPSI } \\
\text { Description }\end{array}$} & \multicolumn{10}{|c|}{ LOKASI PENELITIAN - Study Sites } & \multirow{2}{*}{$\begin{array}{l}\text { Rata-Rata/ } \\
\text { Mean }\end{array}$} \\
\hline & St. 01 & St. 02 & St. 03 & St. 04 & St. 05 & St. 06 & St. 07 & St. 08 & St. 09 & St. 10 & \\
\hline $\begin{array}{l}\text { Jumlah } \\
\text { Individu/Individual } \\
\text { Numbers } \\
\left(\text { per } 350 \mathrm{~m}^{2}\right)\end{array}$ & & & & & & & & & & & \\
\hline $\begin{array}{l}\text { Ikan Major } \\
\text { Ikan Target } \\
\text { Ikan Indikator }\end{array}$ & $\begin{array}{r}827 \\
148 \\
6 \\
\end{array}$ & $\begin{array}{r}3.236 \\
249 \\
15 \\
\end{array}$ & $\begin{array}{r}918 \\
317 \\
16 \\
\end{array}$ & $\begin{array}{r}787 \\
160 \\
42 \\
\end{array}$ & $\begin{array}{r}1.55 \\
2 \\
129 \\
23\end{array}$ & $\begin{array}{r}365 \\
76 \\
15 \\
\end{array}$ & $\begin{array}{r}228 \\
144 \\
3 \\
\end{array}$ & $\begin{array}{r}242 \\
170 \\
11 \\
\end{array}$ & $\begin{array}{r}102 \\
116 \\
14 \\
\end{array}$ & $\begin{array}{r}1.27 \\
6 \\
132 \\
20 \\
\end{array}$ & $\begin{array}{r}953 \\
164 \\
17 \\
\end{array}$ \\
\hline $\begin{array}{l}\text { Jumlah Jenis / } \\
\text { Species Numbers }\end{array}$ & & & & & & & & & & & \\
\hline $\begin{array}{l}\text { Ikan Major } \\
\text { Ikan Target } \\
\text { Ikan Indikator }\end{array}$ & $\begin{array}{r}30 \\
23 \\
2\end{array}$ & $\begin{array}{r}31 \\
25 \\
3 \\
\end{array}$ & $\begin{array}{r}26 \\
22 \\
3\end{array}$ & $\begin{array}{r}22 \\
20 \\
5\end{array}$ & $\begin{array}{r}24 \\
24 \\
5\end{array}$ & $\begin{array}{r}16 \\
19 \\
4\end{array}$ & $\begin{array}{r}31 \\
26 \\
2\end{array}$ & $\begin{array}{r}34 \\
28 \\
2 \\
\end{array}$ & $\begin{array}{r}23 \\
31 \\
4\end{array}$ & $\begin{array}{r}34 \\
37 \\
3 \\
\end{array}$ & $\begin{array}{r}27 \\
26 \\
3\end{array}$ \\
\hline
\end{tabular}

Tabel 4. Indeks ekologis ikan terumbu karang menurut letak stasiun penelitian

Table 4. Ecological indices of reef fishes based on the study sites

\begin{tabular}{|c|c|c|c|c|c|c|c|c|c|c|}
\hline \multirow{3}{*}{$\begin{array}{l}\text { KATEGORI } \\
\text { Categories }\end{array}$} & \multicolumn{10}{|c|}{ STASIUN PENELITIAN / Study Sites } \\
\hline & 5 & ชั & ஜ & J & 48 & $\mathscr{8}$ & ડ & ஜ & 용 & 으 \\
\hline & $\dot{\omega}$ & $\dot{\omega}$ & க் & $\dot{\omega}$ & $\dot{\omega}$ & $\dot{\omega}$ & $\dot{\omega}$ & ஸ் & ஸ் & $\dot{\omega}$ \\
\hline Jumlah Jenis /Species Number & 55 & 59 & 51 & 47 & 53 & 39 & 59 & 64 & 58 & 74 \\
\hline Kepadatan/Density - Individual $/ \mathrm{m}^{2}$ & 2,8 & 10 & 3,6 & 2,8 & 4,8 & 1,4 & 1,0 & 1,2 & 0,6 & 4,0 \\
\hline Richness Index, R1 & 7,8 & 7,1 & 7,0 & 6,7 & 7,0 & 6,2 & 9,8 & 10,4 & 10,5 & 10,0 \\
\hline Simpson Index, D & 0,1 & 0,1 & 0,1 & 0,1 & 0,2 & 0,1 & 0,1 & 0,04 & 0,04 & 0,1 \\
\hline Shannon Weaver Index, H & 3,0 & 2,5 & 2,7 & 2,8 & 2,1 & 2,8 & 3,4 & 3,6 & 3,5 & 2,8 \\
\hline Evenness Index, E & 0,8 & 0,6 & 0,7 & 0,7 & 0,5 & 0,8 & 0,8 & 0,9 & 0,9 & 0,6 \\
\hline
\end{tabular}

\section{Ikan Major}

Dalam penelitian ini tercatat sebanyak 93 spesies ikan kelompok major yang tergolong dalam 14 suku. Kelompok ikan major didominasi oleh10 spesies seperti Apogon of gilberti, Chrysiptera springeri, Chrysiptera hemicyanea, Archamia fucata, Eviota bifasciata, Cheilodipterus quinquelineatus, Cheilodipterus artus, Chromis viridis, Neopomacentrus anabatoides dan Chromis ternatensis (Tabel 5). Jenis Chrysiptera springeri dan Chrysiptera hemicyanea, yang dikenal dengan nama dagang blue divil adalah komoditas ikan hias dengan permintaan cukup tinggi.

Jenis-jenis ikan karang kelompok major lainnya dan tergolong ikan hias yang ditemukan di lokasi penelitian antara lain Pomacentrus moluccensis, Sphaeramia nematoptera, Diproctacanthus xanthurus, Dascyllus trimaculatus (stadiun anakan), Paracheilinus filamentosus, Amphiprion ocellaris, Plagiotremus rhinorhynchus, Pomacentrus auriventris, Coris gaimard (stadiun anakan), Diademichthys lineatus, Amphiprion perideraion, Centropyge bicolor (stadiun anakan), Aspindontus taeniatus, dan Nemateleotris magnifica.

\section{Ikan Karang Target}

Dalam penelitian ini, kelompok ikan target yang teridentifikasi adalah 89 spesies. Jenis-jenis ikan target yang berpotensi sebagai ikan konsumsi tergolong dalam 19 suku. Kehadiran jenisnya di setiap stasiun bervariasi (Tabel 3). Namun beberapa jenis ekonomis tinggi dari kelompok ikan kerapu (Serranidae), kakap (Lutjanidae), lencam (Lethrinidae) dan baronang (Siganidae) dijumpai dengan keragaman yang rendah (Tabel 2).

Kelompok ikan target di perairan pesisir Kendari didominasi oleh jenis ikan ekor kuning (Caesio cuning, sebanyak 5.64\%) dan distribusinya hampir merata di semua lokasi penelitian. Kebanyakan ikan ekor kuning dijumpai masih dalam stadium anakan, seperti pada Stasiun 02 dan Stasiun 03. Ikan ini biasanya hidup secara berkoloni (schooling) dan anakannya dijumpai pada wilayah karang di dalam teluk.

Ikan target yang mendominasi komunitasnya antara lain adalahjenis-jenis Caesio cuning, Scarus flavipectoralis, Chlorurus bleekeri, Scarus ghoban, Caesio caerulaurea, Pterocaesio pisang, Oxycheilinus 
celebicus, Siganus canaliculatus, Ctenochaetus striatus dan Scarus quoyi (Tabel 5). Urutan selanjutnya dari komposisi kehadiran jenis menurut jumlah individunya disajikan pada Tabel 6 .

Tabel 5. Urutan komposisi ikan karang dari kelompok ikan major

Table 5. Composition levels of reef fishes for the major group

\begin{tabular}{|c|c|c|c|c|}
\hline NO & JENIS / Species & SUKU/ Families & $\begin{array}{c}\text { EKOR / } \\
\text { Individual }\end{array}$ & $\begin{array}{c}\text { KOMPOSISI } \\
\text { PARSIALI } \\
\text { Partial Composition } \\
(\%)\end{array}$ \\
\hline 1 & Apogon cf gilberti & APOGONIDAE & 1695 & 14,95 \\
\hline 2 & Chrysiptera springeri & POMACENTRIDAE & 970 & 8,55 \\
\hline 3 & Chrysiptera hemicyanea & POMACENTRIDAE & 869 & 7,66 \\
\hline 4 & Archamia fucata & APOGONIDAE & 551 & 4,86 \\
\hline 5 & Eviota bifasciata & GOBIDAE & 524 & 4,62 \\
\hline 6 & Cheilodipterus quinquelineatus & APOGONIDAE & 508 & 4,48 \\
\hline 7 & Cheilodipterus artus & APOGONIDAE & 426 & 3,76 \\
\hline 8 & Chromis viridis & POMACENTRIDAE & 341 & 3,01 \\
\hline 9 & Neopomacentrus anabatoides & POMACENTRIDAE & 230 & 2,03 \\
\hline 10 & Chromis ternatensis & POMACENTRIDAE & 224 & 1,98 \\
\hline 11 & Neopomacentrus azysron & POMACENTRIDAE & 218 & 1,92 \\
\hline 12 & Chrysiptera rollandi & POMACENTRIDAE & 216 & 1,90 \\
\hline 13 & Plectroglyphidodon lacrymatus & POMACENTRIDAE & 214 & 1,89 \\
\hline 14 & Pomacentrus moluccensis & POMACENTRIDAE & 190 & 1,68 \\
\hline 15 & Sphaeramia nematoptera & APOGONIDAE & 188 & 1,66 \\
\hline 16 & Pomacentrus alexanderae & POMACENTRIDAE & 173 & 1,53 \\
\hline 17 & Archamia zosterophora & APOGONIDAE & 163 & 1,44 \\
\hline 18 & Neopomacentrus filamentosus & POMACENTRIDAE & 156 & 1,38 \\
\hline 19 & Nectamia bandanesis & APOGONIDAE & 149 & 1,31 \\
\hline 20 & Pomacentrus lepidogenys & POMACENTRIDAE & 145 & 1,28 \\
\hline 21 & Amblyglyphidodon curacao & POMACENTRIDAE & 130 & 1,15 \\
\hline 22 & Amblyglyphidodon ternatentis & POMACENTRIDAE & 126 & 1,11 \\
\hline 23 & Cirrhilabrus solorensis & LABRIDAE & 102 & 0,90 \\
\hline 24 & Thalassoma lunare & LABRIDAE & 86 & 0,76 \\
\hline 25 & Chrysiptera oxycephala & POMACENTRIDAE & 80 & 0,71 \\
\hline 26 & Amblyglyphidodon leucogaster & POMACENTRIDAE & 72 & 0,63 \\
\hline 27 & Pseudanthias hutchtii & ANTHIIDAE & 56 & 0,49 \\
\hline 28 & Diproctacanthus xanthurus & LABRIDAE & 52 & 0,46 \\
\hline 29 & Pomacentrus cuneatus & POMACENTRIDAE & 51 & 0,45 \\
\hline 30 & Thalassoma amblycephalum & LABRIDAE & 45 & 0,40 \\
\hline 31 & Halichoeres melanurus & LABRIDAE & 36 & 0,32 \\
\hline 32 & Chromis amboinensis & POMACENTRIDAE & 34 & 0,30 \\
\hline 33 & Halichoeres hortulanus & LABRIDAE & 29 & 0,26 \\
\hline 34 & Halichoeres leucurus & LABRIDAE & 27 & 0,24 \\
\hline 35 & Pomacentrus amboinensis & POMACENTRIDAE & 26 & 0,23 \\
\hline 36 & Premnas biaculeatus & POMACENTRIDAE & 24 & 0,21 \\
\hline 37 & Amphiprion clarkii & POMACENTRIDAE & 23 & 0,20 \\
\hline 38 & Pseudocheilinus hexataenia & LABRIDAE & 23 & 0,20 \\
\hline 39 & Zanclus cornutus & ZANCLIDAE & 21 & 0,19 \\
\hline 40 & Neoglyphidodon nigrosis & POMACENTRIDAE & 19 & 0,17 \\
\hline 41 & Pomacentrus chrysurus & POMACENTRIDAE & 19 & 0,17 \\
\hline 42 & Dascyllus trimaculatus & POMACENTRIDAE & 17 & 0,15 \\
\hline 43 & Labroides dimidiatus & LABRIDAE & 16 & 0,14 \\
\hline 44 & Chaetodonoplus mesoleucus & POMACANTHIDAE & 13 & 0,11 \\
\hline 45 & Abudefduf sexfasciatus & POMACENTRIDAE & 12 & 0,11 \\
\hline 46 & Pomacentrus brachialis & POMACENTRIDAE & 12 & 0,11 \\
\hline 47 & Paracheilinus filamentosus & LABRIDAE & 12 & 0,11 \\
\hline 48 & Pseudocheilinus octotaenia & LABRIDAE & 12 & 0,11 \\
\hline 49 & Amphiprion ocellaris & POMACENTRIDAE & 11 & 0,10 \\
\hline 50 & Plagiotremus rhinorhynchus & BLENNIIDAE & 11 & 0,10 \\
\hline
\end{tabular}




\begin{tabular}{|c|c|c|c|c|}
\hline 51 & Hemiglyphidodon plagiometopon & POMACENTRIDAE & 10 & 0,09 \\
\hline 52 & Halichoeres chloropterus & LABRIDAE & 10 & 0,09 \\
\hline 53 & Thalassoma hardwickii & LABRIDAE & 10 & 0,09 \\
\hline 54 & Halichoeres nebulosus & LABRIDAE & 9 & 0,08 \\
\hline 55 & Macropharyngodon ornatus & LABRIDAE & 9 & 0,08 \\
\hline 56 & Pomacentrus auriventris & POMACENTRIDAE & 8 & 0,07 \\
\hline 57 & Parapercis clathrata & PINGUIPEDIDAE & 8 & 0,07 \\
\hline 58 & Aeoliscus strigatus & AULOSTOMIDAE & 7 & 0,06 \\
\hline 59 & Canthigaster papua & TETRAODONTIDAE & 7 & 0,06 \\
\hline 60 & Amphiprion frenatus & POMACENTRIDAE & 6 & 0,05 \\
\hline 61 & Pomacentrus coelestis & POMACENTRIDAE & 6 & 0,05 \\
\hline 62 & Pomacentrus simsiang & POMACENTRIDAE & 6 & 0,05 \\
\hline 63 & Coris gaimard & LABRIDAE & 6 & 0,05 \\
\hline 64 & Diademichthys lineatus & GOBIESOCIDAE & 5 & 0,04 \\
\hline 65 & Paracirritites fosteri & CIRRHITIDAE & 5 & 0,04 \\
\hline 66 & Coris variegata & LABRIDAE & 5 & 0,04 \\
\hline 67 & Amphiprion perideraion & POMACENTRIDAE & 4 & 0,04 \\
\hline 68 & Anampses twistii & LABRIDAE & 4 & 0,04 \\
\hline 69 & Bodinaus mesothorax & LABRIDAE & 4 & 0,04 \\
\hline 70 & Halichoeres lamari & LABRIDAE & 4 & 0,04 \\
\hline 71 & Labrichthys unilineatus & LABRIDAE & 4 & 0,04 \\
\hline 72 & Novaculichthys taeniourus & LABRIDAE & 4 & 0,04 \\
\hline 73 & Pterogogus ocellatus & LABRIDAE & 4 & 0,04 \\
\hline 74 & Canthigaster valentini & TETRAODONTIDAE & 4 & 0,04 \\
\hline 75 & Aulostomus chinensis & AULOSTOMIDAE & 3 & 0,03 \\
\hline 76 & Abudefduf vaigiensis & POMACENTRIDAE & 3 & 0,03 \\
\hline 77 & Pomacentrus armillatus & POMACENTRIDAE & 3 & 0,03 \\
\hline 78 & Pomacentrus bankanensis & POMACENTRIDAE & 3 & 0,03 \\
\hline 79 & Stethojulis bandanensis & LABRIDAE & 3 & 0,03 \\
\hline 80 & Fistularia petimba & FISTULARIIDAE & 2 & 0,02 \\
\hline 81 & Dascyllus aruanus & POMACENTRIDAE & 2 & 0,02 \\
\hline 82 & Halichoeres annularis & LABRIDAE & 2 & 0,02 \\
\hline 83 & Halichoeres solorensis & LABRIDAE & 2 & 0,02 \\
\hline 84 & Stethojulis zatima & LABRIDAE & 2 & 0,02 \\
\hline 85 & Meiacanthus grammistes & BLENNIIDAE & 2 & 0,02 \\
\hline 86 & Valenciennea strigata & GOBIDAE & 2 & 0,02 \\
\hline 87 & Arothron nigropunctatus & TETRAODONTIDAE & 2 & 0,02 \\
\hline 88 & Centropyge bicolor & POMACANTHIDAE & 1 & 0,01 \\
\hline 89 & Centropyge vrolikii & POMACANTHIDAE & 1 & 0,01 \\
\hline 90 & Leptojulis cyanopleura & LABRIDAE & 1 & 0,01 \\
\hline 91 & Macropharyngodon negrosensis & LABRIDAE & 1 & 0,01 \\
\hline 92 & Aspindontus taeniatus & BLENNIIDAE & 1 & 0,01 \\
\hline 93 & Nemateleotris magnifica & GOBIDAE & 1 & 0,01 \\
\hline
\end{tabular}


Tabel 6. Urutan komposisi parsial ikan karang dari kelompok ikan target

Table 6. Partial composition levels of reef fishes for the target group

\begin{tabular}{|c|c|c|c|c|}
\hline NO & J E N I S / Species & SUKU/ Families & $\begin{array}{l}\text { EKOR / } \\
\text { Individual }\end{array}$ & $\begin{array}{c}\text { KOMPOSISI } \\
\text { PARSIAL/ } \\
\text { Partial } \\
\text { Composition } \\
(\%)\end{array}$ \\
\hline 1 & Caesio cuning & CAESIONIDAE & 619 & 5,46 \\
\hline 2 & Scarus flavipectoralis & SCARIDAE & 106 & 0,93 \\
\hline 3 & Chlorurus bleekeri & SCARIDAE & 70 & 0,62 \\
\hline 4 & Scarus ghoban & SCARIDAE & 70 & 0,62 \\
\hline 5 & Caesio caerulaurea & CAESIONIDAE & 46 & 0,41 \\
\hline 6 & Pterocaesio pisang & CAESIONIDAE & 42 & 0,37 \\
\hline 7 & Oxycheilinus celebicus & LABRIDAE & 42 & 0,37 \\
\hline 8 & Siganus canaliculatus & SIGANIDAE & 39 & 0,34 \\
\hline 9 & Ctenochaetus striatus & ACANTHURIDAE & 38 & 0,34 \\
\hline 10 & Scarus quoyi & SCARIDAE & 35 & 0,31 \\
\hline 11 & Pterocaesio tessellata & CAESIONIDAE & 32 & 0,28 \\
\hline 12 & Scarus rivulalatus & SCARIDAE & 30 & 0,26 \\
\hline 13 & Cheilinus fasciatus & LABRIDAE & 25 & 0,22 \\
\hline 14 & Lutjanus biguttatus & LUTJANIDAE & 24 & 0,21 \\
\hline 15 & Parupeneus multifasciatus & MULLIDAE & 24 & 0,21 \\
\hline 16 & Selar leptolepis & CARANGIDAE & 20 & 0,18 \\
\hline 17 & Diploprion bifasciatum & GRAMMISTIDAE & 19 & 0,17 \\
\hline 18 & Scarus niger & SCARIDAE & 19 & 0,17 \\
\hline 19 & Siganus vulpinus & SIGANIDAE & 19 & 0,17 \\
\hline 20 & Pterocaesio chrysozona & CAESIONIDAE & 16 & 0,14 \\
\hline 21 & Naso hexacanthus & ACANTHURIDAE & 14 & 0,12 \\
\hline 22 & Lutjanus carponatus & LUTJANIDAE & 13 & 0,11 \\
\hline 23 & Siganus punctatissimus & SIGANIDAE & 13 & 0,11 \\
\hline 24 & Acanthurus auranticavus & ACANTHURIDAE & 12 & 0,11 \\
\hline 25 & Hemigymnus melapterus & LABRIDAE & 11 & 0,10 \\
\hline 26 & Siganus doliatus & SIGANIDAE & 11 & 0,10 \\
\hline 27 & Ctenochaetus binotatus & ACANTHURIDAE & 11 & 0,10 \\
\hline 28 & Zebrasoma scopas & ACANTHURIDAE & 11 & 0,10 \\
\hline 29 & Cephalopholis boenack & SERRANIDAE & 10 & 0,09 \\
\hline 30 & Pentapodus trivittatus & NEMIPTERIDAE & 10 & 0,09 \\
\hline 31 & Scolopsis bilineata & NEMIPTERIDAE & 9 & 0,08 \\
\hline 32 & Scolopsis margaritifer & NEMIPTERIDAE & 9 & 0,08 \\
\hline 33 & Parupeneus barbarinus & MULLIDAE & 9 & 0,08 \\
\hline 34 & Sargocentron caudimaculatum & HOLOCENTRIDAE & 8 & 0,07 \\
\hline 35 & Phempheris oualensis & PHEMPHERIDIDAE & 8 & 0,07 \\
\hline 36 & Epibulus insidiator & LABRIDAE & 8 & 0,07 \\
\hline 37 & Cheilinus trilobatus & LABRIDAE & 7 & 0,06 \\
\hline 38 & Balistapus undulatus & BALISTIDAE & 7 & 0,06 \\
\hline 39 & Scolopsis cillata & NEMIPTERIDAE & 6 & 0,05 \\
\hline 40 & Lutjanus decussatus & LUTJANIDAE & 6 & 0,05 \\
\hline 41 & Choerodon anchorago & LABRIDAE & 6 & 0,05 \\
\hline
\end{tabular}




\begin{tabular}{|c|c|c|c|c|}
\hline 42 & Siganus puellus & SIGANIDAE & 6 & 0,05 \\
\hline 43 & Cephalopholis microprion & SERRANIDAE & 5 & 0,04 \\
\hline 44 & Odonus niger & BALISTIDAE & 5 & 0,04 \\
\hline 45 & Suflamen chrysopterus & BALISTIDAE & 5 & 0,04 \\
\hline 46 & Caranx melampygus & CARANGIDAE & 5 & 0,04 \\
\hline 47 & Cephalopholis cyanostigma & SERRANIDAE & 4 & 0,04 \\
\hline 48 & Scolopsis affinins & NEMIPTERIDAE & 4 & 0,04 \\
\hline 49 & Scolopsis lineata & NEMIPTERIDAE & 4 & 0,04 \\
\hline 50 & Siganus guttatus & SIGANIDAE & 4 & 0,04 \\
\hline 51 & Ephinephelus fasciatus & SERRANIDAE & 3 & 0,03 \\
\hline 52 & Plectorhyncus chaetodonoides & HAEMULIDAE & 3 & 0,03 \\
\hline 53 & Dischistodus perspicillatus & POMACENTRIDAE & 3 & 0,03 \\
\hline 54 & Epibulus brevis & LABRIDAE & 3 & 0,03 \\
\hline 55 & Acanthurus lineatus & ACANTHURIDAE & 3 & 0,03 \\
\hline 56 & Zebrasoma veliferum & ACANTHURIDAE & 3 & 0,03 \\
\hline 57 & Suflamen bursa & BALISTIDAE & 3 & 0,03 \\
\hline 58 & Myripristis adusta & HOLOCENTRIDAE & 2 & 0,02 \\
\hline 59 & Ephinephelus merra & SERRANIDAE & 2 & 0,02 \\
\hline 60 & Pentapodus emeryi & NEMIPTERIDAE & 2 & 0,02 \\
\hline 61 & Scolopsis xenochoroa & NEMIPTERIDAE & 2 & 0,02 \\
\hline 62 & Pomacanthus sexstriatus & POMACANTHIDAE & 2 & 0,02 \\
\hline 63 & Chlorurus sordidus & SCARIDAE & 2 & 0,02 \\
\hline 64 & Scarus dimidiatus & SCARIDAE & 2 & 0,02 \\
\hline 65 & Acanthurus guttatus & ACANTHURIDAE & 2 & 0,02 \\
\hline 66 & Acanthurus nigrofuscus & ACANTHURIDAE & 2 & 0,02 \\
\hline 67 & Acanthurus thompsoni & ACANTHURIDAE & 2 & 0,02 \\
\hline 68 & Ctenochaetus tominiensis & ACANTHURIDAE & 2 & 0,02 \\
\hline 69 & Balistapus viridescens & BALISTIDAE & 2 & 0,02 \\
\hline 70 & Anyperodon leucogrammicus & SERRANIDAE & 1 & 0,01 \\
\hline 71 & Cephalopholis miniata & SERRANIDAE & 1 & 0,01 \\
\hline 72 & Cromileptis altevelis & SERRANIDAE & 1 & 0,01 \\
\hline 73 & Ephinephelus aerolatus & SERRANIDAE & 1 & 0,01 \\
\hline 74 & Ephinephelus faveatus & SERRANIDAE & 1 & 0,01 \\
\hline 75 & Plectropomus oligocanthus & SERRANIDAE & 1 & 0,01 \\
\hline 76 & Plectropomus maculatus & SERRANIDAE & 1 & 0,01 \\
\hline 77 & Pentapodus caninus & NEMIPTERIDAE & 1 & 0,01 \\
\hline 78 & Priacanthus hamrur & PRIACANTHIDAE & 1 & 0,01 \\
\hline 79 & Lutjanus fulvus & LUTJANIDAE & 1 & 0,01 \\
\hline 80 & Lethrinus ornatus & LETHRINIDAE & 1 & 0,01 \\
\hline 81 & Monotaxix grandoculis & LETHRINIDAE & 1 & 0,01 \\
\hline 82 & Platax teira & EPHIPPIDAE & 1 & 0,01 \\
\hline 83 & Cheilinus diagrammus & LABRIDAE & 1 & 0,01 \\
\hline 84 & Chlorurus microrhinos & SCARIDAE & 1 & 0,01 \\
\hline 85 & Scarus rubroviolaceus & SCARIDAE & 1 & 0,01 \\
\hline 86 & Siganus coralinus & SIGANIDAE & 1 & 0,01 \\
\hline 87 & Naso lituratus & ACANTHURIDAE & 1 & 0,01 \\
\hline 88 & Paracanthurus hepatus & ACANTHURIDAE & 1 & 0,01 \\
\hline 89 & Caranx orthogramus & CARANGIDAE & 1 & 0,01 \\
\hline
\end{tabular}


Jenis-jenis ikan kerapu yang memiliki nilai ekonomis tinggi dan dijumpai di lokasi penelitian adalah Cephalopholis cyanostigma, Ephinephelus fasciatus, Ephinephelus merra, Anyperodon leucogrammicus, Cephalopholis miniata, Cromileptis altevelis, Ephinephelus aerolatus, Ephinephelus faveatus, Plectropomus oligocanthus, dan Plectropomus maculatus.

Beberapa jenis ikan karang yang memiliki nilai ekonomis tinggi termasuk ikan kakap, lencam, baronang, bibir tebal, kakatua, dan ikan bobara. Kelompok ikan kakap dijumpai dua spesies, yaitu Lutjanus carponatus dan Lutjanus fulvus. Kelompok lencam dijumpai dua spesies, yaitu Lethrinus ornatus dan Monotaxis grandoculis. Kelompok baronang dijumpai 5 spesies dan termasuk Siganus vulpinus, Siganus punctatissimus, Siganus doliatus, Siganus puellus, dan Siganus coralinus. Ikan bibir tebal dari suku Haemulidae hanya dijumpai satu spesies, yaitu Plectorhyncus chaetodonoides. Kelompok ikan kakatua antara lain termasuk Scarus flavipectoralis, Chlorurus bleekeri, Scarus ghoban, Scarus rivulalatus, Scarus niger, Chlorurus microrhinos, dan Scarus rubroviolaceus. Kelompok ikan bobara (travelly) dijumpai dua spesies, yaitu Caranx melampygus dan Caranx orthogramus.

\section{Ikan Indikator}

Jenis-jenis ikan dari suku Chaetodontidae merupakan indikator kesehatan terumbu karang (indicator fish). Jenis indikator yang berhasil diidentifikasi adalah 13 spesies. Jenis-jenis tersebut berasal dari 6 marga, yakni Chaetodon (10 spesies), Heniochus (2 spesies) dan Chelmon (1 jenis). Chaetodon octofasciatus adalah spesies yang paling mendominasi ikan anggota suku Chaetodontidae dengan kelimpahan 0,98\%, kemudian disusul Chaetodon klenii $(0,19 \%)$ dan Chelmon rostratus $(0,12 \%)$ (Tabel 7$)$.

Tabel 7. Urutan komposisi parsialikan kepe-kepe dari kelompok ikan indikator Table 7. Partial composition levels for chaetodont fishes of the indicator group

\begin{tabular}{cllccc}
\hline \hline NO & JENIS / Species & SUKU / Families & $\begin{array}{c}\text { Fungsional } \\
\text { Functional }\end{array}$ & $\begin{array}{c}\text { KOMPOSISI } \\
\text { JUAH } \\
\text { INDIVIDU / } \\
\text { Individual } \\
\text { Numbers }\end{array}$ & $\begin{array}{c}\text { Partial } \\
\text { Composition } \\
\text { Pum }\end{array}$ \\
\hline \hline 1 & & & & 111 & 0,98 \\
2 & Chaetodon octofasciatus & CHAETODONTIDAE & Generalis & 22 & 0,19 \\
3 & Chelmon rostratus & CHAETODONTIDAE & Generalis & 14 & 0,12 \\
4 & Chaetodon trifascialis & CHAETODONTIDAE & Fakultatif & 3 & 0,03 \\
5 & Chaetodon trifasciatus & CHAETODONTIDAE & Obligate & 3 & 0,03 \\
6 & Chaetodon vagabundus & CHAETODONTIDAE & Fakultatif & 3 & 0,03 \\
7 & Chaetodon oxycephalus & CHAETODONTIDAE & Fakultatif & 2 & 0,02 \\
8 & Heniochus acuminatus & CHAETODONTIDAE & Generalis & 2 & 0,02 \\
9 & Chaetodon ephippium & CHAETODONTIDAE & Fakultatif & 1 & 0,01 \\
10 & Chaetodon ocellicaudus & CHAETODONTIDAE & Fakultatif & 1 & 0,01 \\
11 & Chaetodon semeion & CHAETODONTIDAE & Fakultatif & 1 & 0,01 \\
12 & Chaetodon speculum & CHAETODONTIDAE & Generalis & 1 & 0,01 \\
13 & Heniochus singularis & CHAETODONTIDAE & Obligat & 1 & 0,01 \\
\hline \hline
\end{tabular}

Berdasarkan persentasi kehadirannya, maka Chaetodon octofasciatus merupakan jenis yang paling umum ditemukan di hampir semua lokasi penelitian, yaitu dijumpai di 8 stasiun. Di setiap lokasi stasiun tidak dijumpai banyak jenis ikan indikator, terutama variasi jumlah jenis antara stasiun hanya berkisar pada 2 spesies dan 5 spesies. Umumnya kepe-kepe yang ditemukan bersifat fakultatif (memiliki banyak pilihan makanan). Lainnya bersifat generalis yang menyukai makanan selain polips karang dan hanya sedikit yang berdifat obligat karang (pemakan polips karang).

\section{Kepadatan Stok}

Kepadatan stok ikan karangdijumpai dengan kisaran antara 0,6 ekor $/ \mathrm{m}^{2}$ sampai 10 ekor $/ \mathrm{m}^{2}$. Kepadatan stok pada stasiun 02, 03, 05 dan 10 relatif lebih tinggi dari stasiun lainnya (Tabel 4). Pada stasiun dengan kepadatan stok yang tinggi umumnya dijumpai adanya populasi-populasi yang bersifat schooling (bergerombol), seperti, semua jenis dari suku Apogonidae yang melimpah pada perairan tenang dan terlindung. Beberapa jenis lainnya yang bersifat bergerombol adalah dari suku Pomacentridae, seperti 
dari marga Amblyglyphidodon, Neopomacentrus, Plectroglyphidodon Pomacentrus, dan suku Labridae seperti jenis Cirrhilabrus solorensis, atau dari Suku Gobiiedae seperti jenis Eviota bifasciata. Jenis-jenis tersebut dijumpai merata di sepenjang transek dengan kelimpahan yang tinggi. Sementara jenis-jenis ikan karang dari kelompok ikan target umumnya dijumpai dalam bentuk individual atau soliter, kecuali jenis-jenis dari suku Caesionidae hadir dalam schooling.

Variasi kepadatan stok per transek $\left(350 \mathrm{~m}^{2}\right)$ antar lokasi untuk masing-masing kelompok ikan Major, Target dan Indikator disajikan pada Tabel 4. Stasiun 02, Stasiun 05 dan Stasiun 10 memiliki kepadatan stok ikan major yang relatif tinggi, seperti juga ikan target pada Stasiun 02 dan Stasiun 03. Kelimpahan ikan indikator yang tertinggi dijumpai pada Stasiun 04, dimana jenis Chaetodon octofasciatus terdapat dalam jumlah yang tinggi dan dijumpai merata pada semua stasiun.

\section{Bahasan}

Indeks keanekaragaman jenis/spesies ikan karang di semua stasiun penelitian masuk dalam kriteria "sedang" sampai "tinggi" (Mason, 1981). Hal ini menunjukkan bahwa ekosistem terumbu karang di perairan pesisir Kendari hanya sebagian yang masih dalam kondisi yang baik. Belum ada petunjuk terjadinya perubahan lingkungan perairan yang ekstrim yang berpengaruh pada komunitas ikan karang (Jones et al., 2004). Di beberapa lokasi kajian sudah terdeteksi adanya dominasi jenis ikan dengan menurunnya keanekaragaman ikan karang yang ditemukan pada Stasiun 02, 03, 05 dan 10.

Indeks keanekaragaman di pesisir Kendari masih lebih rendah dibandingkan keanekaragaman di wilayah lain. Lokasi yang semakin menjauh dari daratan utama Kendari umumnya memiliki keanekaragaman ikan karang yang lebih tinggi. Hasil penelitian lain dengan area penelitian yang lebih luas ke arah selatan, pada wilayah propinsi Sulawesi Tenggara dengan 25 titik stasiun, mendapatkan total 399 spesies ikan karang dan keanekaragaman tertinggi ditemukan di Wakatobi dengan jumlah jenis antar stasiun berkisar antara104 sampai 160 spesies dan nilai semua indeks keanekaragaman di atas 3,62 (Edrus \& Utama, 2019). Hasil penelitian lain di Buton menyatakan bahwa Indeks keanekaragaman pada ke 10 stasiun semua di atas nilai 3,5 dan jumlah jenis yang ditemukan 292 spesies dengan kisaran antara stasiun terendah 62 spesies dan tertinggi 147 spesies (Edrus \& Wibowo, 2014). Sementara hasil penelitian ini pada perairan pesisir Kendari, hanya menemukan 195 spesies dengan kisaran jumlah jenis terendah 39 spesies dan tertinggi 74 spesies. Perubahan struktur komunitas ikan dari lokasi ke lokasi, atau respon ikan pada perubahan habitat pada umumnya, dapat dihubungkan pada tipe relung (niches) yang hilang dan degradasi tutupan terumbu karang (Amesbury, 1981; Jones \& Syms, 1998; Halford et al., 2004).

Dalam kaidah statistik distribusi populasi, keanekaragaman komunitas ikan karang sesungguhnya berhubungan dengan jumlah kehadiran spesies dan pola distribusi jumlah dari masing-masing populasi spesies yang menyusun komunitas tersebut. Menurut Odum (1975), semakin tinggi jumlah kehadiran spesies dapat dikatakan semakin tinggi pula indeks kekayaan jenis $(R)$ dan ini dapat menjadi petunjuk sederhana dari tingginya keanekaragaman makluk hidup. Kemudian kondisi kemerataan populasi (indeks E) dan dominasi populasi (indeks D) dalam komunitas membentuk (mempengaruhi) hasil akhir perhitungan indeks keanekaragaman $(\mathrm{H})$, dimana indeks $\mathrm{H}$ mewakili kedua indeks tersebut. Kemerataan populasi yang tinggi dan mendekati nilai 1 (Tabel 4) adalah petunjuk bahwa lingkungan memberikan kesempatan yang sama untuk semua populasi berkembang dan hal ini sebagai tanda habitat yang baik (Odum,1975). Sebaliknya ketika nilai indeks dominasi mendekati nol, hal ini berartitidak ada populasi yang mendominasi dalam komunitas ikan karang, sehingga distribusi populasi seperti itu adalah petunjuk habitat yang baik pula (Odum,1975; Arief \& Edrus, 2010). Stasiun terbaik adalah St.8 dan St 9, sedangkan stasiun lainnya seperti St 1, 3, 4, 6,dan 7 tergolong baik, sementara stasiun terburuk adalah Stasiun 05 dan tergolong kurang baik adalah St 2 dan St 10.

Komposisi jenis ikan karang terutama didominasi oleh jenis-jenis ikan yang biasa menyukai wilayah teluk yang sedikit keruh dan hidup bergerombol atau schooling (Mallela et al., 2007), seperti kelompok ekor kuning (Caesio spp.), pisang-pisang (Pterocaesio spp.), kakatua (Scaridae spp.), kelompok beseng (Apogonidae) dan betok (Chrysiptera spp.). Dominasi individual dalam komunitas ikan yang diperlihatkan oleh jenis-jenis schooling tersebut, umumnya menyebabkan perhitungan indeks keanekaragaman (H) menurun karena nilai keseimbangan antara populasi rendah. Oleh karena itu pada stasiun-stasiun 02,03,05 dan 10 indeks $\mathrm{H}$ relatif kecil dari Indeks $\mathrm{H}$ stasiun lainnya (Tabel 4). Hal tersebut menyebabkan keanekaragaman di lokasi beberapa stasiun perairan pesisir Kendari tergolong rendah, terutama jika dibandingkan dengan hasil penelitian ikan karang di perairan karang sekitar Pulau Buton (Edrus \& Wibowo, 2014; Hadi et al., 2017; Tuti et al., 2011) serta perairan karang Wakatobi (Tuti et al., 2017) dan Banggai Kepulauan (Edrus \& Saputro, 2009). 
Secara umum ikan kelompok major, ikan target konsumsi dan ikan indikator hadir dalam komposisi yang tidak biasa, yakni kelompok major $75 \%$, kelompok target $23 \%$ dan kelompok indikator $2 \%$, sedangkan komposisi yangdijumpai di wilayah terumbu karang yang sehat lainnya umumnya dengan rasio major $60 \%$, target $30 \%$ dan indikator $10 \%$ (Edrus \& Suhendra, 2007; Edrus \& Saputro, 2009). Perubahan struktur komunitas ikan dalam merespon perubahan kompleksitas habitat telah dipercaya memiliki keterkaitan pada kualitas terumbu karang, meskipun mekanismenya belum dimengerti (Feary et al., 2007a dan 2007b). Perubahan komunitas ikan biasanya adalah respon terhadap perubahan lingkungan dan ganguan yang beragam. Setiap ikan karang memiliki fungsi ekologis khusus pada mikro habitat atau niches, dimana ikan biasa ditemukan di tempat khusus tersebut di suatu terumbu karang. Hilangnya mikro habitat tersebut akan berpengaruh pada gangguan fungsional ikan dan hal ini dapat menjadi alasan dari adanya pergantian struktur komunitas ikan karang (Booth, 2002; Garpe et al., 2006; Graham et al., 2006; Jones et al., 2004).

Kehadiran kelompok ikan indikator seperti ikan kepe-kepe dari suku Chaetodontidae adalah penting untuk memprediksi kondisi karang pada umumnya (Pratchett et al., 2013). Kelompok ikan indikator mempunyai asosiasi yang kuat dengan terumbu karang, karena sebagian besar pakan alami jenis anggota suku ini adalah polip-polip karang sehingga ikan ini merupakan bio-indikator terhadap kesehatan ekosistem terumbu karang (Riansyah et al., 2018; Navaro \& Bouchon, 1989 dan Reese, 1981). Berdasarkan FishBase (2013), saat ini tercatat sebanyak 65 spesies anggota suku Chaetodontidae di Indonesia, sedangkan dalam penelitian di perairan pesisir Kendari teridentifikasi hanya 5 spesies . Data ini menunjukkan bahwa perairan pesisir Kendari memiliki kekayaan jenis ikan kepe-kepe yang sangat rendah jika dibandingkan dengan perairan lainnya, seperti perairan Buton 25 spesies (Edrus \& Wibowo, 2014), Kendari sebanyak 16 spesies , Lamalera 19 spesies, dan Banggai 14 spesies (Wibowo et al., 2013) serta Ternate 31 spesies (Utama et al., 2019). Jenis-jenis Chaetodon octofasciatus, Chaetodon klenii, dan Chelmon rostratus di lokasi penelitian dijumpai melimpah (Tabel 7 ). Jenis $C$. octofasciatus dan C. rostratus mampu beradaptasi dan lebih umum dijumpai pada ekosistem terumbu karang yang mengalami masalah turbiditas akibat sedimentasi, dan C. klenii yang dapat beradaptasi pada terumbu karang yang kritis (Allen \& Erdmann, 2012), tidak seperti kebanyakan jenis ikan kepe-kepe lainnya sebagai obligat koralivora (pemakan polip karang) yang dipertimbangkan sebagai jenis ikan indikator positif kesehatan terumbu karang. (Reese, 1981; Pratchett \& Berumen, 2008). Perbedaan dalam kelimpahan ikan kepe-kepe antar lokasi dan antar zona karang dihubungkan dengan kehadiran bentuk komposisi fungsional (Obligat koralivora, fakultatif koralivora, atau non-koralivora/generalis) dan kebiasaan makan ikan kepe-kepe yang sering berhubungan dengan variasi kelimpahan karang keras scleractinia (Pratchett et al., 2013). Ketiga jenis yag mendominasi tersebut bersifat generalis dan fakultatif dalam kebiasaan makan (Table 7), sehingga sebaran kehadirannya lebih luas mulai perairan keruh sampai perairan jernih (Pratchett et al., 2006; Pratchet, 2005). Hal ini menunjukkan ekosistem terumbu karang di perairan pesisir Kendari dalam kondisi yang kurang baik secara spasial. Kondisi ini merupakan petunjuk bahwa perairan pesisir Kendari memiliki masalah pada kolom air, terutama dari sedimentasi daratan saat musim hujan.

Menurut kriteria kepadatan Djamali \& Darsono (2005), kepadatan stok ikan karang umumnya tergolong rendah pada semua stasiun. Kelimpahan ikan karang di pesisir perairan Kendari untuk 9 stasiun penelitian adalah tergolong "sangat jarang" $(1-5 \mathrm{ekor} /$ $\mathrm{m}^{2}$ ) dan untuk Stasiun 02 tergolong "jarang" (5-10 ekor $\left./ \mathrm{m}^{2}\right)$. Kepadatan stok ikan di area terumbu karang bergantung pada rugositas atau kompleksitas tofografi bentukan hidup karang (benthic lifeform) dan sifat fungsional ikan karang yang hidup pada relung ekologi yang khusus (niches) (Luckhurst \& Luckhurst, 1978; Mc Manus et al., 1981). Hal ini menentukan jumlah ikan menurut komposisi jenisnya, seperti adanya dominasi ikan-ikan yang bergerombol (schooling) dan tinggi rendahnya jumlah ikan-ikan individual (soliter) dan berpasangan. Nilai kelimpahan ikan berkorelasi dengan nilai rugositas terumbu (Ilham, 2007).

Terumbu karang dengan persen tutupan karang bercabang (coral branching) yang tinggi umumnya memiliki jumlah populasi yang banyak dari jenis ikanikan bergerombol, seperti kebanyakan suku Pomacentridae dan Labridae di wilayah perairan yang jernih, atau suku Apogonidae di perairan yang sedikit gelap dan terlindung, serta suku Acanthuridae dan Carangidae yang merupakan ikan-ikan pelintas di wilayah terumbu yang terbuka terhadap angin/ombak, atau suku Caesionidae yang menyukai wilayah terumbu karang yang baik terbuka maupun terlindung dari pengaruh angin. Hanya sedikit jenis dari suku Chaetodontidae yang memiliki sifat bergerombol (Bell \& Galzin, 1984; Allen \& Erdmann, 2012; Nurhasinta et al., 2019). Dari beberapa jenis suku ikan bergerombol yang ditemukan dalam penelitian ini (Tabel 5 dan Tabel 6), ada 3 spesies kelompok ikan major dan 1 spesies kelompok ikan target berkoloni 
yang secara signifikan menyumbang dalam jumlah besarkepadatan stok ikan, yaitu suku Apogonidae (Apogon cf gilberti), Pomacentridae (Chrysiptera springeri, Chrysiptera hemicyanea), serta Casionidae (Caesio cuning). Pada kelompok ikan indikator tidak dijumpai bentuk populasi bergerombol, melainkan dijumpai dalam jumlah banyak saja seperti jenis Chaetodon octofasciatus (Tabel 7) yang dapat beradaptasi pada perairan yang sedikit keruh (Allen \& Erdmann, 2012). Hal ini menunjukkan bahwa terumbu karang di tempat penelitian tidak mendukung perkembangan ukuran populasi untuk mencapai tingkat kepadatan yang tinggi. Hasil penelitian P2OLIPI menunjukkan bahwa pada lokasi yang sama dengan penelitian ikan karang ini memiliki kondisi tutupan karang hidup (Hard Corals) yang tergolong sedang atau cukup, $25 \%<\mathrm{HC} \leq 50 \%$ (Hadi et al., 2018).

\section{KESIMPULAN}

Struktur komunitas ikan karang di perairan karang pesisir Kendari dari segi keanekaragaman termasuk rendah, karena sebagian besar lokasi stasiun memiliki indeks keanekaragaman $(\mathrm{H})$ di bawah 3. Kelompok ikan major mendominasi komunitas dengan rasio perbandingan yang tidak biasa, karena ukuran populasi kelompok ikan target tidak berkembang dan kelompok ikan indikator tertekan oleh kondisi perairan yang buruk, seperti ditunjukkan oleh kepadatan stok ikan karang yang rendah pada semua lokasi penelitian, karena populasi dari jenis ikan yang bersifat bergerombol tidak banyak.

\section{PERSANTUNAN}

Kegiatan monitoring ini adalah bagian dari kegiatan Pusat Penelitian Oseanografi-LIPI berkaitan Survei Potensi Karang Hias T.A 2018. Terima kasih diucapkan kepada semua pihak yang telah membantu kelancaran kegiatan ini.

\section{DAFTAR PUSTAKA}

Allen, G.R., \& Erdmann, M.V. (2012). Reef fishes of the East Indies. $1^{\text {st }}$ Vol., $2^{\text {nd }}$ Vol. \& $3^{\text {rd }}$ Vol. (1260 p.). Perth, Australia: Tropical Reef Research.

Amesbury, S. S. (1981). Effects of turbidity on shallow-water reef fish assemblages in Truk, Eastern Caroline Islands. InProceedings of the Fourth International Coral Reef Symposium (p. 155-159). Manilla, Philippnes: Marine Sciences Center, University of the Philippines.
Arief, S., \& Edrus, I.N. (2010). Struktur komunitas ikan karang di Perairan Kabupaten Maluku Barat Daya. J. Lit. Perikan. Ind, 16 (3), 235 - 250. DOI: http://dx.doi.org/10.15578/ jppi.16.3.2010.235-250

Bell, J.D., \& Galzin, R. (1984). Influences of live coral cover on a coral reef fish communities. Mar Ecol Prog Ser, 1, 265-274.

Booth, D.J. (2002). Distribution changes after settlement in six species of damsel fish (Pomacentridae) in One Tree Island lagoon, Great Barrier Reef. Mar. Ecol Prog. Ser. 226, 157-164.

Djamali, A., \& Darsono, P. (2005). Petunjuk teknis Lapangan untuk Penelitian Ikan Karang di Ekosistem terumbu Karang. Materi Kursus. Jakarta: Pusat Dokumentasi dan Informasi IImiahLIPI.

Edrus, I.N., \& Suhendra, D. (2007). Sumber daya ikan karang. Dalam S. Hartini dan G. B. Saputro (Eds.) Sumberdaya Alam Pulau Kecil Terluar, Pulau Manterawu (p. 47). Cibinong, Bogor: Pusat Survei Sumber Daya Alam Laut, BAKOSURTANAL.

Edrus, I.N., \& Saputro, G.B. (2009). Struktur Komunitas Ikan Karang di Perairan Kabupaten Banggai Kepulauan. J. Lit. Perikan. Ind, 15 (4), 321-332. DOI: http://dx.doi.org/10.15578/ jppi.15.4.2009.321-332

Edrus, I.N., \& Wibowo, K. (2014). Status komunitas ikan karang pasca implementasi program COREMAP di Kabupaten Buton Propinsi Sulawesi Tenggara. Dalam Yosephine Tuti (Ed.) Kesehatan Terumbu Karang dan Ekosistem Terkait Kabupaten Buton Sulawesi Tenggara 2013 (p. 46). Jakarta:Pusat Penelitian Oseanografi- Lembaga IImu Pengetahuan Indonesia.

Edrus, I.N., \& Utama, R.S. (2019). Struktur komunitas ikan karang di Perairan Sulawesi Tenggara. Makalah pada Indonesian Coral Reefs Conference(16 hal.), Semarang, 4 Juli 2019. Semarang: COREMAP-CTI-P2O LIPI-Universitas Deponegoro.

English, S., Wilkinson, C., \& Baker, V. (1997). Survey manual for tropical marine resources (p. 368). Townsville, Australia: Australian Institute of Marine Science.

Feary, D.A., Almany, G.R., Jones, G.P., \& McCormick, M.I. (2007a). Coral degradation and the structure 
of tropical reef Fish communities. Mar. Ecol. Prog. Ser. 333,243-248. DOI: 10.3354/ meps 333243

Feary, D.A., Almany, G.R., Jones, G.P., \& McCormick, M.I. (2007b). Habitat choice, recruitment and the response of coral reef fishes to coral degradation (11 pp.). Oecologia, Springer Publ. DOI 10.1007/ s00442-007-0773-4.

Garpe, K.C., Yahya, S.A.S. Lindahl, U., \& Öhman, M.C.(2006). Long-term effects of the 1998 bleaching event on reeffish assemblages. Mar. Ecol. Prog. Ser. 315, 237-247.

Graham N.A.J., Wilson, S.K., Jennings, S., Polunin, V.C., Bijoux, J.P., \& Robinson, J. (2006). Dynamic fragility of oceanic coral reef ecosystems. Proc. Natl. Acad. Sci. USA 103, 8425-8429.

Green, A.L., \& Bellwood, D.R. (2009). Monitoring functional groups of herbivorous reef fishes as indicators of coral reef resilience-A practical guide for coral reef managers in the Asia Pacific region (70 pp). Gland, Switzerland: IUCN working group on Climate Change and Coral Reefs.

Gomez, E.D., \& Yap, H.T. (1988). Monitoring reef condition. In R.A. Kenchingthon and B.E.T. Hudson (Eds) Coral Reef Management Handbook (p. 171). Jakarta, Indonesia: Unesco Publisher.

Hadi, T.A., Suharsono., Tuti, M.I.Y., Abrar, M., Sulha, S., Hendrik, A.W.C., Masteria, Y.P., Edrus, I.N., Pramuji., ......(2017). Monitoring kesehatan terumbu karang dan ekosistem terkait lainnya, Kabupaten Buton, Sulawesi Tenggara 2017 (95 hal). Jakarta: COREMAP-CTI, P20-LIPI.

Hadi, T.A., Giyanto., Prayudha, B., Hafizt, M., Budiyanto, A., \& Suharsono. (2018). Status terumbu karang indonesia. 2018 (p. 26.). Jakarta, Indonesia:Puslit Oseanografi-LIPI.

Halford, A, Cheal, A.J., Ryan, D.A.J., \& Williams, D.M. (2004). Resilience to large-scale disturbance in coral and Fish assemblages on the Great Barrier Reef Ecology, 85, 1892-1905.

Ilham. (2007).Keterkaitan kondisi dan rugositas terumbu karang dengan kelimpahan dan keragaman ikan karang di Pulau Badi Kabupaten Pangkep. Skripsi. Jurusan IImu Kelautan, Fak. IImu Kelautan dan Perikanan, Universitas Hassanuddin, Makassar
Jones, G.P., \& Syms, C.(1998). Disturbance, habitat structure and the ecology of fishes on coral reefs. Aust. J. Ecol. 23, 287-297 doi:10.1111/j.14429993.1998.tb00733.x

Jones GP, McCormick, M.I., Srinivasan, M., \& Eagle, J.V. (2004). Coral decline threatens fish biodiversity in marine reserves. Proc. Natl. Acad. Sci USA 101, 8251-8253. https://doi.org/10.1073/ pnas.0401277101

Kuiter, R.H., \& Tonozuka, T. (2001). Pictorial guide to Indonesian reef fishes. Seaford VIC 3198 , Australia: Zoonetics Publc.

Lieske, E., \& Myers, R.(1997). Reef fishes of the world (p. 425).Jakarta, Indonesia: Periplus Edition.

Luckhurst, B., \& Luckhurst, K.(1978). Analysis of the influence of substrate variable on coral reef communities. Mar Biol. 49, 469-478.

Mc Manus, J., Miclat, R., \& Palaganas, V.(1981). Coral and fish community structure of Sombrero Island at Batangas, Philippines. Proc ${ }^{4 \text { th }}$ Int Coral Reef Symp 2, 271-280.

Mallela, J., Roberts, C., Harrod, C., \& Goldspink, C. R. (2007). Distributional patterns and community structure of Caribbean coral reef fishes within a river-impacted bay. Journal of Fish Biology, 70, 523-537. https://doi.org/10.1111/j.10958649.2007.01323.x

Masuda, H., Amaoka, K., Araga, C.,Uyano, T., \& Yoshino, T. (1984). The fishes of the Japan Archipelago $2^{\text {nd }}$ vol(p.435).Tokai, Japan: Tokai University Press.

Mason, C.F. (1981). Biology of freshwater pollution. Longman Scientific and Technical. Singapore: Longman Singapore Publisher Ptc. Ltd.

Navaro, Y. B., \& Bouchon, C. (1989). Correlations between chaetodontid fishes and coral communities of the Gulf of Aqaba (Red Sea). Envi. Biol. of Fishes. 25 (1-3), 47-60.

NOAA, (2019). Coral reefs in the Pacific. Providing scientific information to support ecosystem approaches to management and conservation of coral reefs. Pacific Islands Fisheries Science Center. 8 pages. https://www.fisheries. noaa.gov / pacific-islands/ecosystems/coral-reefs-pacific. Last Update on 03/11/2019. 
Nurhasinta, Umroh., \& Syari, I.A. (2019). Kelimpahan ikan Chaetodontidae dan Pomacentridae di ekosistem terumbu karang Pulau Ketawai dan Pulau Gusung Asam, Kabupaten Bangka Tengah. Maspari Journal. 11(2), 97 - 114. DOI: http://doi.org/ 10.36706/maspari.v11i2.9476

Nybakken, J.W. (1992). Biology laut, suatu pendekatan ekologis. Jakarta: Gramedia.

Obura, D.O., \& Grimsdith, G. (2009). Resilience assessment of coral reefs - assessment protocol for coral reefs, focusing on coral bleaching and thermal stress (p.70). Gland, Switzerland: IUCN working group on Climate Change and Coral Reefs.

Odum, E.P. (1975). Fundamental of ecology (p. 574). Philadelphia: E.B. Sounders Co.

Pratchett, M.S. (2005). Dietary overlap among coralfeeding butterflyfishes (Chaetodontidae) at Lizard Island, Northern Great Barrier Reef. Marine Biology, 148(2), 373-382.

Pratchett, M.S., Wilson, S.K., \& Baird, A.H. (2006). Declines in the abundance of Chaetodon butterflyfishes following extensive coral depletion. Jurnal of Fish Biology, 69 (5), 1.2691.280. https:// doi.org/10.1111/j.10958649.2006.01161.x

Pratchett, M.S., \& Berumen, M.L. (2008). Interspecific variation in distributions and diets of coral reef butterflyfishes (Teleostei: Chaetodontidae).Journal of Fish Biology,73 (7), 1730-1747. https://doi.org/ 10.1111/j.1095-8649.2008.02062.x

Pratchett, M.S., Graham, N.A.J., \& Cole, A. J. (2013). Specialist corallivores dominate butterflyfish assemblages in coral dominated reef habitats. Journal of Fish Biology, 82(4), 1177-1191. doi: 10.1111/jfb.12056.

Reese, E.S., (1981). Predation on corals by fishes of the family Chaetodontidae: implications for conservation and management of coral reef ecosystems. Bull. Mar. Sci. 31, 594-604.
Riansyah, A., Hartono, D., \& Kusuma, A.B. (2018). Ikan Kepe-kepe (Chaetodontidae) sebagai bioindikator kerusakan perairan ekosistem terumbu karang Pulau Tikus. Majalah IImiah Biologi Biosfera, A Scientific Journal, 35(2), 103-110.

Roberts, C.M., \& Ormond, R.F.G.(1987). Habitat complexity and coral reef fish diversity and abundance on Red Sea fringing reefs. Marine Ecology, 41, 1 - 8. DOI: 10.3354/meps041001

Stan \& Hauter, D. (2011). Diet \& Feeding ProfileButterflyfish Family Chaetodontidae. About.com Saltwater Aquariums Guides. Diakses tgl 24 Agustus 2011, jam 09.00.

Tuti, M.I.Y., Suharti, S.R., \& Salatalohi, A. (2011). Pemantauan terumbu karang Buton (p. 90). Jakarta, Indonesia : COREMAP-P2O LIPI Publ.

Tuti, M.I.Y., Suharti, S.R., Cappenberg, H.A.W., Edrus, I.N., Darmawan, I.W.E., Hadi, T.A., Utama, R.S, Budianto, A., Salatalohi, A., \& Sulha Siti. (2017). Monitoring kesehatan terumbu karang dan ekosistem terkait lainnya: di Kabupaten Wakatobi, Sulawesi Tenggara 2017. (p. 119). Jakarta, Indonesia: COREMAP-CTI, P20-LIPI Publ.

Utama, R.S., Edrus, I.N., \& Makatipu, P.C. (2019). Komunitas ikan karang di Pulau Ternate dan sekitarnya. Oseanologi dan Limnologi di Indonesia, 4(1), 53-69.

Wenger, A. (2009). Effect of suspended sediment on early life stages of planktivorous damselfish. $P h D$ Thesis.Coral Reef Ecology Laboratory, Associate Professor Mark Ian McCormick, James Cook University, Townsville Australia.

Wibowo, K., Adrim, M., \& Makatipu, P.C. (2013). Community structure of Chaetodontidae in the west of Banda Sea. Mar. Res. Indonesia, 38(1), $1-8$.

Wilson, S.K, Graham, N.A.J., Pratchett, M., Jones, G.P., \& Polunin, N.V.C. (2006). Multiple disturbances and the global degradation of coral reefs: are reeffishes at risk or resilient? Global Change Biol. 12, 2.220-2.234. 